ORIGINAL ARTICLE

\title{
CHITOSAN AS ANTIFUNGAL IN CHANNA STRIATA COLLAGEN- CHITOSAN FOR WOUND HEALING
}

\author{
Ary Andini ${ }^{1}$, Endah Prayekti ${ }^{2 *}$ \\ ${ }^{1,2}$ Departement of Health Analyst, Health Faculty, University of Nahdlatul Ulama Surabaya \\ *Correspondent author: aryandini@unusa.ac.id
}

\section{ARTICLE INFO}

Article history:

Submited: July, 282019

Received in revised form

August 2019

Accepted: August, 272019

\section{Keywords:}

Channa striata, collagen,

chitosan, fungal, wound

\begin{abstract}
Background: The Snakehead fish (Channa striata) contains high protein that was mostly used for treatment during healing process. It could be developed as well as a mixtured with chitosan for wound dressing. Chitosan known as biodegradability, biocompatibility and bioactivity biopolymers. The aim of this study was to know the effect of combination of concentrations between chitosan and collagen of Snakehead fish skin and scales on fungal total number recovered from the composite. Methods: Snakehead fish skin and scales was treated by soaking in $2 \%$ $\mathrm{HCl}$ solvent for 48 hours to obtain collagen from its filtrate. Filtrate obtained continued to neutralize with $1 \mathrm{M} \mathrm{NaOH}$ until soluble collagen appeared. Collagen obtained in this study then mixed with $2 \%$ chitosan liquid to make wound dressing in various concentrations group. Results: Combination of colagen mixture in this study were chitosan liquid only as control, $25 \%$ collagen- $75 \%$ chitosan $(\mathrm{C} 1), 50 \%$ collagen-50\% chitosan (C2) and $75 \%$ collagen- $25 \%$ chitosan (C3). The study results showed that on Control, $\mathrm{C} 1$ and $\mathrm{C} 2$ group there was no fungal growth, but on $\mathrm{C} 3$ group there was fungal growth with total counting about $2,43 \times 10^{3} \mathrm{CFU}$. Based on statistically test showed that there was discrepancy for each group with p-value was $0,02$ ( $\mathrm{p}<0,05)$. Conclusion: This research showed that chitosan content could contributed as an anti-fungal.
\end{abstract}

@2019 Medical and Health Science Journal. 10.33086/mhsj.v3i2.1197

\section{INTRODUCTION}

Based on the results of the Basic Health Research (Riskesdas) in 2013, the prevalence of burn injury increased from $25.9 \%$ in 2007 to $47.7 \%$ in 2013 , with a percentage of respondents reaching $70.9 \%$ and $70 \%$ injuries (Ministry of Health Republic of Indonesia, 2013). The enhancement of burn injury prevalence in Indonesia caused skin treatment needs increased, therefore alternative skin treatment could fulfill those demands.Based on the richness of Indonesian nature, reearcher tried to make wound dressing from combination of chitosan and collagen from snakehead fish for getting skin care with economical and efficient to use.

Correspondence: Ary Andini, Endah Prayekti

@ 2019 Medical and Health Science Journal. 10.33086/mhsj.v3i2.1197

Available at http://journal2.unusa.ac.id/index.php/MHSJ
Collagen from fish properties was better than livestock and poultry due to halal for use, free from Foot and Mouth Disease (PMK), Bovine Spongioform Encelopathy (BSE), Transmission of Spongioform Encephalopathy (TSE) and Food and Mouth Disease (FMD) (Singh et al., 2010; Andini A, 2016; Andini et al, 2017). Also, collagen from fish had a low immunoreactive risk in body because had low hydroxyproline to make more elastic than collagen from livestock and poultry (Andini A, 2016; Andini et al, 2017).

Wound healing processes need moist state to increase epithelialization and stimulate proliferation and migratory epithelium, increase growth factor activity to maintain transportation of nutrients and oxygen cells (Hidayat, 2013). 
Collagen could help wound healing process due to stimulate fibroblasts formation, then stimulating new tissue formation and new epithelial tissue (Andini, 2016). One of the collagen sources that could be used is collagen from snakehead fish (Channa striata).

The research used collagen from skin and scales of snakehead fish (Channa striata) then combined with chitosan becomes collagen-chitosan composite for wound healing. Based on Rosmawati (2018) study shown collagen of snakehead fish skin about $8,85 \pm 0,84 \%$ with high amino acid of glycin, prolin and hydroxyproline. Chitosan is known as non-toxic, biodegradable and renewable materials that shown as biocompatibility devices with positive effect on wound healing (Ratnawati et al, 2013). In pharmacology, chitosan used for the controlled release of drugs and wound healing due to their hydrogel properties.

(Akakuru et al., 2018) This Research was a preliminary study to know about collagen-chitosan composite properties on fungal growth by counting fungal total.

\section{METHODS}

The snakehead skin and scales were taken from Tanggulangin sub-district in Sidoarjo city, East Java, Indonesia. Then, it was extracted with $2 \% \mathrm{HCl}$ solution for 48 hours in chill condition. After that, filtered and neutralized filtrat by using 1 $\mathrm{M} \mathrm{NaOH}$ solution until getting soluble collagen. Mixtured collagen soluble with 2\% chitosan liquid to make collagen-chitosan composite into various group concentration i.e chitosan liquid only as control group, $25 \%$ collagen- $75 \%$ chitosan as $\mathrm{C} 1$ group, $50 \%$ collagen-50\% chitosan as $\mathrm{C} 2$ group and $75 \%$ collagen-25\% chitosan as C3 group. Then, mixture of each composit group was pouring to the mold with $2-3 \mathrm{~mm}$ in height and cover with sterile gauze then dry for 5 days.

Fungal count in collagen mixture of each composite was determine by diluting $0,1 \mathrm{gr}$ composite in $9,9 \mathrm{~mL} 0,85 \%$ natrium clorida solution. After diluting, the solution brought to plate and grown in potato dextrose agar medium at $37^{\circ} \mathrm{C}$ for 2 until 3 days.

\section{RESULTS}

The results of counting the total number of fungal obtained could be seen in table 1 and figure 1. Result of statistical analysis could be seen in table 2. The research used Kruskal Wallis test due to had distribution normal data with $\mathrm{p}$-value $=$ $0,799(p>0,05)$ but had not homogeneous data with $\mathrm{p}$-value $=0,03(\mathrm{p}>0,05$.

Tabel 1. Total number of fungal on collagenchitosan composit

\begin{tabular}{|c|c|c|}
\hline Group & Mean (CFU) & $\underline{\mathrm{SD}}$ \\
\hline Control & 0 & 0 \\
\hline $\mathrm{C} 1$ & 0 & 0 \\
\hline $\mathrm{C} 2$ & 0 & 0 \\
\hline $\mathrm{C} 3$ & $2,43 \times 10^{3}$ & $1,2 \times 10^{3}$ \\
\hline
\end{tabular}

Tabel 2. Results of statiscally Kruskal Wallis test using SPSS

\begin{tabular}{cccc}
\hline Group & Mean \pm SD & $\mathrm{N}$ & p-value \\
Control & 0,00 & 4 & \\
$\mathrm{C} 1$ & 0,00 & 4 & 0,02 \\
$\mathrm{C} 2$ & 0,00 & 4 & \\
$\mathrm{C} 3$ & $2,43 \times 10^{3}$ & 4 & \\
\hline
\end{tabular}

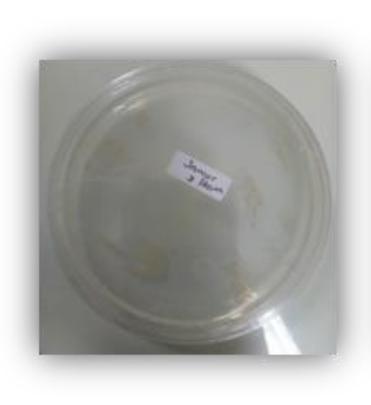

(a)

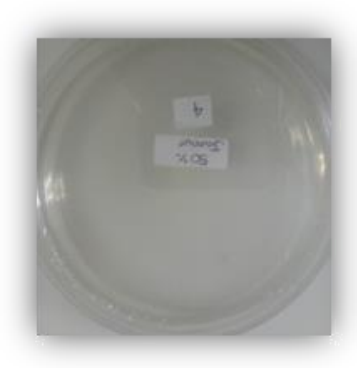

(c)

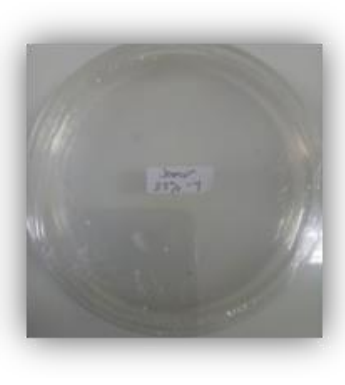

(b)

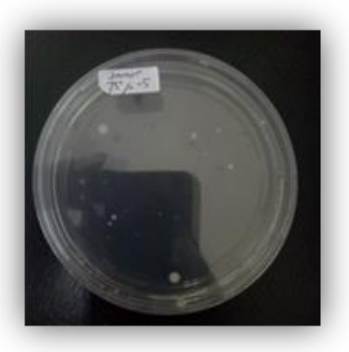

(d) 
Figure 1. Fungal on each composite group. (a) Control group; (b) $\mathrm{C} 1$ group; (c) $\mathrm{C} 2$ group; (d) $\mathrm{C} 3$ group.

Based on the result in table 1 showed that on Control, C1 and C2 group had not fungal growth with fungal total were 0 for each. But, on C3 group had fungal growth was 2425. Figure of fungal growth for each group could be observed in figure

1. Statistically result showed that there were discrepancy of total number of fungal for each group with $\mathrm{p}$-value about $0,02(\mathrm{p}<0,05)$.

\section{DISCUSSION}

Chitosan had biological properties i.e biodegradability with non-toxic or allergic and eco-friendly, biocompatibility with no antigenic properties, and bioactivity with bacteriostatic, haemostatic, immunologic, analgesic, antiinflamatory, anticoagulant etc (Cheba, 2011).

Based on the research shown on Control, $\mathrm{C} 1$ and $\mathrm{C} 2$ group had no fungal growth, but on $\mathrm{C} 3$ group had contamination of fungal with total counting about $2,43 \times 10^{3} \mathrm{CFU}$ and statistically test showed that there was discrepancy for each group with $\mathrm{p}$-value was $0,02(\mathrm{p}<0,05)$. It was proven that chitosan had antifungal properties. The higher chitosan composition, then the higher antifungal properties in Channa striata collagenchitosan wound dressing. Chitosan as antifungal biopolymers had been proven in several studies. The study of Lee et al. (2016) showed a decrease in viability in Penicillium italicum after being exposed to several chitosan fractions.

The reduction was mainly due to the inhibition effect of chitooligomers-F2 (CO-F2) on spore germination via disruption of $\mathrm{Ca}^{2+}$ ion channel. The research of Xing et al. (2018) described about the flow of chitosan inhibition in Ceratocystis fimbriata. Chitosan which was attached to the plasma membrane and the intercellular component would disrupt membrane cells which leads to leakage of intracellular components, especially $\mathrm{K}^{+}$ions. This leak causes changes in morphology, membrane depolarization and $\mathrm{H}^{+} / \mathrm{K}^{+}$ATPase activity, which leads to cell death.

There was a linear relationship between molecular weight and particle size that proved statistically (Ing et al., 2012). Thus, the nano-form of chitosan particles has the potential to be a strong and safe natural antifungal agent.

The Snakehead fish contains high protein that was mostly used as a treatment during for healing process in either invasive or passive surgery in Indonesia. Snakehead fish contains three main amino acids i.e glycine, glutamine and arginine. Glycine amino acid plays a role in collagen synthesis which plays an important role in connective tissue, glutamine plays a role during the inflammatory phase and proliferation of wound healing while acting as an energy source, while Arginine plays a role in immune function and stimulates endothelial cell function (Rahayu et al, 2016). Collagen from fish could stimulate fibroblasts formation, then stimulating new tissue formation and new epithelial tissue (Andini, 2016) due to contains proline and glycine. Glycine was used as natural moisturizing factor on skin and induced collagen synthesis to accelerating burn healing (Andini, 2017).

This research showed that chitosan content could contributed as an anti-fungal. It could be seen if the higher chitosan content in composite, the composite would not be contaminated with fungi. Conversely the higher of collagen content in the composite, the higher contamination of composite.

\section{CONCLUSION}

As conclusion of the research were on Control, $\mathrm{C} 1$ and $\mathrm{C} 2$ group had no fungal growth, but on $\mathrm{C} 3$ group had contamination of fungal with total counting about 2,43 x $10^{3} \mathrm{CFU}$ and statistically test showed that there was discrepancy for each group with $p$-value was $0,02(p<0,05)$.

\section{ACKNOWLEDGEMENT}

The Ministry of Research, Technology and Higher Education Indonesia (Kemenristek Dikti) 
that granted the research and Institute of Research and Community Service (LPPM) Nahdlatul Ulama University of Surabaya that supported the research.

\section{REFERENCES}

1. Ahmed S. Ikram S. 2016. Chitosan Based Scaffolds and Their Applications in Wound Healing. Elsevier, Achievements in the Life Sciences 10: 27-37

2. Aisyah. Mufarikoh Z. Andini A. 2017. Pengaruh Pemberian Topikal Ekstrak Kolagen Kulit Ikan Lele Sangkuriang (Clarias Gariepinus Var) Terhadap TNF- $\alpha$ dan Jumlah Fibroblast Pada Luka Bakar Derajat Dua Tikus Wistar. Medical and Health Science Journal, Vol. 1, No. 1, Februari

3. Akakuru OU, Louis H. Amos PI. Akakukru OC, Nosike EI, Ogulewe EF. 2018. The Chemistry of Chitin and Chitosan Justifying their Nanomedical Utilities. Biochem Pharmacol (Los Angel) 2018, 7:1. DOI: 10.4172/21670501.1000241

4. Andini A, Handajani R, Soetjipto. 2017. Sangkuriang Catfish (Clarias gariepinus var) Skin Extract Activity on Fibroblast and Collagen Synthesis for Skin Burn Healing. Proceeding Surabaya International Health Conference, Vol 1, No. 1

5. Andini A. 2016. Pengaruh Pemberian Topikal Ekstrak Kolagen Kulit Ikan Lele Sangkuriang (Clarias gariepinus var) terhadap Penyembuhan Luka Bakar Tikus strain Wistar.Thesis.Program Studi Ilmu Kedokteran Dasar, Fakultas Kedokteran, Universitas Airlangga

6. Hidayat TSN. 2013. Peran Topikal Ekstrak Gel Aloe Vera pada Penyembuhan Luka Bakar Derajat Dalam pada Tikus. Karya Akhir, Departemen/SMF Ilmu Bedah Plastik Rekonstruksi dan Estetik, Fakultas Kedokteran/RSUD Dr. Soetomo, Surabaya

7. Cheba BA. 2011. Chitin and Chitosan: Marine Biopolymers with Unique Properties and Versatile Applications. Global Journal of Biotechnology \& Biochemistry 6 (3): 149-153, 2011

8. Ing LY. Sarwar A. Zin NM. Katas H. 2012. Antifungal Activity of Chitosan Nanoparticles and Correlation with Their Physical Properties.
International Journal of Biomaterials. Volume 2012, 9 pages. DOI: 10.1155/2012/632698

9. (Ministry of Health Republic of Indonesia (Kementrian Kesehatan Republik Indonesia). 2013. Riset Kesehatan Dasar: Riskesdas 2013. Badan Penelitian dan Pengembangan Kesehatan Kementrian Kesehatan Republik Indonesia

10. Lee CG. Koo JC. Park JK. 2016. Antifungal Effect of Chitosan as $\mathrm{Ca}^{2+}$ Channel Blocker. Plant Pathology Journal 32(3): 242-25

11. Mohandas A. Deepthi S. Biswas R. Jayakumar R. 2018. Chitosan based metallic nanocomposite scaffolds as antimicrobial wound dressings. Science Direct, Bioactive Materials 3

12. Nagori BP. Solanki R. 2011. Role Medicinal Plants in Wound Healing. Research Journal of Medicine Plant 5(4): 392-405

13. Rahayu P. Marcelline F. Sulistyaningrum E. Suhartono MT, Tjandrawinata RR. 2016. Potential effect of striatin (DLBS0333), a bioactive protein fraction isolated fromChanna striata for wound treatment. Elsevier, Asian Pac J Trop Biomed 6(12): 1001-1007

14. Ratnawati A. R Djoni I. Supardi A. 2013. Sintesis dan Karakterisasi Kolagen dari Teripang-Kitosan sebagai Aplikasi Pembalut Luka. Media Jurnal Fisika dan Terapannya, Volume: 1 - No. 2 Terbit: 4--2013

15. Rosmawati. 2018. Potensi Kolagen Ikan Gabus (Channa striata) sebagai Gelatin Alternatif dan Aplikasinya dalam Penolaha Sosis Berbasis Meat By-Product Sapi. [Disertasi]. Sekolah Pascasarjana, Universitas Hasanuddin

16. Singh P. Benjakul S. Maqsood S. KishimuraH. 2010. Isolation and Characterisation of Collagen Extracted from the Skin os Striped Catfish (Pangasionodonhipopthalmus). $\quad$ Food Chemistry;124: 97-105

17. Vig K. Chaudhari A. Tripathi S. Dixit S. Sahu R. Pillai S. Dennis VA. Singh SR. 2017. Advances in Skin Regeneration Using Tissue Engineering. Intenational Journal of Molecular Sciences, 18, 789

18. Xing K. Xing Y. Liu Y. Zhang Y. Shen X. Li X. Miao X. Feng Z. Peng X. Qin S. 2018. Fungicidal Effect of Chitosan via Inducing Membrane Disturbance Against Ceratocystis fimbriata. Carbohidrat Polymers Journal, 195, 95-103 